\title{
Species richness, diversity and specificity of the parasites of bream Abramis brama (L.) and perch Perca fluviatilis L. in the estuary of the Odra River, Poland
}

\author{
E. SOBECKA, M. SŁOMIŃSKA
}

\begin{abstract}
Division of Fish Diseases, Agricultural University of Szczecin, ul. Kazimierza Królewicza 4, 71-550 Szczecin, Poland, E-mail: esobecka@fish.ar.szczecin.pl
\end{abstract}

\begin{abstract}
Summary
The parasitological studies were carried out on bream and perch from brackish water of Pomeranian Bay and the Szczecin Lagoon - a mouth of the Odra River. Bream and perch hosted 21 and 13 parasitic species, respectively. The species richness and diversity of parasites were much higher for bream and the abundance of parasites in bream was nearly four-fold higher than that in perch. Faunistic similarity of both parasite communities was low. The dominant group of parasites in both fish hosts was digeneans. Five species were specialists of bream, while only one species was a perch specialist. Five new host records have been reported in Poland for the following species: Myxobolus dispar, Hysterothylacium aduncum, Khawia sinensis, Echinorhynchus gadi and Pomphorhynchus laevis.
\end{abstract}

Keywords: parasites; carp bream; European perch; brackish water; Poland

\section{Introduction}

The Szczecin Lagoon and Pomeranian Bay constitute a part of the Odra River estuary. They remain under the influence of a large inflow of the fresh water supplied primarily by the Odra River. Pomeranian Bay is also an area where the fresh water mixes with the water of the Baltic. The salinity ranges from $3 \%$, where the fresh water flows in, to $7 \%$ on the edge of the marine water (Majewski, 1974). Favourable environmental conditions and abundance of food encourage both freshwater fishes and those inhabiting the southern Baltic Sea to perform environmental and spawning migrations. Therefore, both water bodies are particularly interesting research areas.

Bream and perch are very common freshwater fishes in both, Pomeranian Bay and the Szczecin Lagoon. The two fish species belonging to different families exhibit differ- rent lifestyles. In the present paper, we compare the parasite fauna of bream and perch living in this area.

Material and methods

Bream (60 specimens) and perch (55 specimens) were caught by means of bottom trawling gear (in Pomeranian Bay) and set gear (in the Szczecin Lagoon) in November 2002 and from March until August 2003. The mean total length of bream was $32.5 \pm 4.0 \mathrm{~cm}$, and that of perch 21.7 $\pm 3.2 \mathrm{~cm}$. The mean body weighs were $780.0 \pm 271.2 \mathrm{~g}$ and $199.3 \pm 84.1$ g. Parasitological examination focused on the skin, vitreous humour, eye lens, mouth and nasal cavities, gills, heart, gonads, spleen, gastrointestinal tract, kidneys, swim bladder, and peritoneum. The parasites found in the fish were determined by viewing the specimens in transient light immersed in glycerine, lactic acid, or preserved in 75 $\%$ ethyl alcohol. Helminths were stained using alum carmine and mounted into Canada balsam.

The results were analysed by use of the following traits:

1. Quantitative descriptors of parasite populations such as prevalence $(P \%)$, mean infection intensity $(M i)$, relative density $(R d)$, and frequency $(F \%)$ (Pojmańska, 1993; Czachorowski, 2004);

2. Species richness $(S)$, Shannon-Weaver species diversity index $\left(H^{\prime}\right)$, Berger-Parker species dominance index $(D)$ and Jaccard faunistic similarity coefficient (Wxy) (Trojan, 1992; Kennedy \& Pojmańska, 1996);

3 . The prevalence values allowed classification of the species as dominant $(\mathrm{P}>50 \%)$, common $(10-50 \%)$, rare $(4$ $-10 \%$ ), or sporadic $(\mathrm{P}<4 \%$ ) (according to Pojmańska, 1993);

4. Parasite communities of bream and perch were characterised (Esch et al., 1988). Considering host specificity, the parasites were classified as generalists or specialists (Price, 1980).

Statistical analyses were carried out using Statistica 7.0 software package. 


\section{Results}

All fish were infected with parasites. The parasite component community comprised 1927 individuals (21species) in bream and 465 individuals (13 species) in perch (Table 1).

Table 1. The indices of species richness, dominance and diversity of fish parasites in the estuary of Odra River

\begin{tabular}{lcccc}
\hline $\begin{array}{l}\text { Fish } \\
\text { species }\end{array}$ & $\begin{array}{c}\text { Number of } \\
\text { specimens }\end{array}$ & $\begin{array}{c}\text { Species } \\
\text { richness }\end{array}$ & $\begin{array}{c}\text { Coefficient } \\
\text { of Berger- } \\
\text { Parker } \\
(H)\end{array}$ & $\begin{array}{c}\text { Shannon- } \\
\text { Weaver's } \\
\text { coefficient } \\
\left(H^{\prime}\right)\end{array}$ \\
\hline Bream & 1927 & 21 & 34.8 & 1.9 \\
Perch & 465 & 13 & 39.0 & 1.3 \\
\hline
\end{tabular}

Bream parasites belonged to Myxosporea, Monogenea, Digenea, Cestoda, Nematoda, Acanthocephala, Hirudinea, Mollusca, Copepoda, and Branchiura. In the intestine of seven bream, the tapeworm Khawia sinensis, a parasite of other cyprinids was found for the first time in Poland (Khalil et al. 1994; Jara \& Chodyniecki 1999; Scholz et al. 2001). Perch parasites belonged to Myxosporea, Digenea, Cestoda, Nematoda, Acanthocephala, Hirudinea, and Mollusca. Myxobolus dispar, Hysterothylacium aduncum, Echinorhynchus gadi and Pomphorhynchus laevis, which have been found in perch represent the new host records in Poland.

Among the parasites of both fish species, digeneans exhibited the highest frequency.

The species diversity index $\left(H^{\prime}\right)$ of parasites was higher for bream, while the dominance index $(D)$ was higher in perch (Table 2), that was accompanied by lower species diversity of the perch parasite community. The dominant parasite of bream was Diplostomum spp., digeneans, $M y$ xobolus oviformis, Diplozoon paradoxum, Caryophyllaeus

Table 2. Infection parameters of the species parasitizing bream and perch in the estuary of Odra river

\begin{tabular}{|c|c|c|c|c|}
\hline Species & $\begin{array}{c}\text { Prevalence } \\
{[\%]}\end{array}$ & $\begin{array}{c}\text { Mean } \\
\text { intensity }\end{array}$ & $\begin{array}{c}\text { Relative } \\
\text { density }\end{array}$ & $\begin{array}{c}\mathrm{F} \\
{[\%]}\end{array}$ \\
\hline \multicolumn{5}{|l|}{ Parasites of bream } \\
\hline Myxobolus oviformis (Thelohan, 1882 ) & 28.3 & 11.4 & cysts & \\
\hline Henneguya cutanea (Dogiel \& Petruschewsky, 1933) & 6.7 & 1.8 & cysts & \\
\hline Dactylogyrus falcatus (Wedl, 1857) & 20 & 1.42 & 17 & 0.88 \\
\hline Diplozoon paradoxum (von Nordmann, 1832) & 41.7 & 3.9 & 98 & 5.1 \\
\hline Bucephalus polymorphus (Baer, 1827) & 5 & 3.0 & 9 & 0.47 \\
\hline Asymphylodora imitans (Mühling, 1898) & 6.7 & 2.8 & 11 & 0.6 \\
\hline Diplostomum spp., larvae & 73.34 & 15.25 & 671 & 34.82 \\
\hline Posthodiplostomum cuticula (von Nordmann, 1832), larvae & 10 & 24.67 & 148 & 7.68 \\
\hline Paracoenogonimus ovatus (Katsurada, 1914) & 5 & 26 & 78 & 4.05 \\
\hline Caryophyllaeus laticeps (Pallas, 1781) & 48.34 & 13.31 & 386 & 20.03 \\
\hline Caryophyllaeides fennica (Schneider, 1902) & 13.34 & 4.38 & 35 & 1.82 \\
\hline Khawia sinensis (Hsu, 1935) & 10 & 1.17 & 7 & 0.36 \\
\hline Philometra ovata (Zeder, 1803) & 3.34 & 11.5 & 23 & 1.19 \\
\hline Raphidascaris acus (Bloch, 1779) & 6.67 & 1.25 & 5 & 0.26 \\
\hline Acanthocephalus lucii (Müller, 1776) & 15 & 2.23 & 21 & 1.09 \\
\hline Piscicola geometra (Linnaeus, 1761) & 35 & 4.19 & 88 & 4.57 \\
\hline Caspiobdella fadejewi (Epstein, 1961) & 1.67 & 2 & 2 & 0.10 \\
\hline Unionidae spp. & 1.67 & 29 & 29 & 1.50 \\
\hline Ergasilus sieboldi (von Nordmann, 1832) & 36.67 & 7.3 & 73 & 3.79 \\
\hline Tracheliastes maculatus (Kollar, 1835) & 16.67 & 1.8 & 18 & 0.93 \\
\hline Argulus foliaceus (Linnaeus, 1758) & 8.34 & 1.4 & 7 & 0.36 \\
\hline \multicolumn{5}{|l|}{ Parasites of perch } \\
\hline Myxobolus dispar (Thelohan, 1895) & 1.82 & 1 & single cyst & \\
\hline Henneguya psorospermica (Thélohan, 1892) & 1.82 & 1 & single cyst & \\
\hline Bunodera luciopercae (Muller, 1776) & 47.27 & 6.19 & 161 & 34.61 \\
\hline Tylodelphys clavata (von Nordmann, 1832), larvae & 41.82 & 7.87 & 181 & 38.92 \\
\hline Diphyllobothrium sp., larvae & 12.73 & 1.43 & 10 & 2.15 \\
\hline Eubothrium crassum (Bloch, 1779), larvae & 21.82 & 1.92 & 23 & 4.95 \\
\hline Triaenophorus nodulosus (Pallas, 1781), larvae & 32.73 & 3.17 & 57 & 12.25 \\
\hline Proteocephalus percae (Müller, 1780) & 9.09 & 1.8 & 9 & 1.94 \\
\hline Hysterothylacium aduncum (Rudolphi, 1802) & 20 & 1.64 & 18 & 3.87 \\
\hline Echinorhynchus gadi (Zoega, 1776) & 1.82 & 1.5 & 3 & 0.65 \\
\hline Pomphorhynchus laevis (Müller, 1776) & 1.82 & 1 & 1 & 0.22 \\
\hline Piscicola geometra (Linnaeus, 1761) & 1.82 & 1 & 1 & 0.22 \\
\hline Unionidae spp. & 1.82 & 1 & 1 & 0.22 \\
\hline
\end{tabular}


laticeps, Caryophyllaeides fennica, Ergasilus sieboldi, and Tracheliastes maculatus belonged to common parasites and Henneguya cutanea, Bucephalus polymorphus, Asymphylodora imitans, Posthodiplostomum cuticola, Raphidascaris acus, and Argulus foliaceus were rare parasitic species. Caspiobdella fadejewi and Unionidae spp. sporacally occurred.

No parasite found in perch belonged to the dominant species group. Common parasites were Bunodera luciopercae, Tylodelphis clavata, Diphyllobothrium sp., Eubothrium crassum, and Triaenophorus nodulosus. Proteocephalus percae ocured rarely and remaining Myxobolus dispar, Henneguya psorospermica, Echinorhynchus gadi, Pomphorhynchus laevis, Piscicola geometra, and Unionidae spp. were sporadic.

The faunistic similarity of both parasite component communities was very low $(6.45 \%)$. A. foliaceus and Unionidae spp. were the only taxa common for both fish species.

The community of intestinal parasites was taxonomically diverse; in bream it comprised of 2 digenean species $(B$. polymorphus, $A$. imitans), 3 tapeworms (C. laticeps, $C$. fennica, $K$. sinensis), a nematode $R$. acus, and an acanthocephalan Acanthocephalus lucii. Component community of intestinal parasites of perch included one digenean species (B. luciopercae), 3 tapeworms (E. crassum, P. percae, Diphyllobothrium sp.), one nematode (H. aduncum), and one acanthocephalan (E. gadi).

The community of gill parasites of bream was composed of spores in the cysts of Myxobolus oviformis, as well as 2 monogeneans (Dactylogyrus falcatus, Diplozoon paradoxum) and the copepod Ergasilus sieboldi. On the gills of perch, Myxobolus dispar and Henneguya psorospermica were found. Unionidae spp. were found to occur on the gills of both fish host species.

The community of skin and fin parasites of bream was composed of spores $H$. cutanea, metacercariae of $P$. cuticola, Paracoenogonimus ovatus, 2 leeches ( $P$. geometra, C. fadejewi), and 1 copepod (Tracheliastes maculatus). With the exception of $P$. geometra, no parasite species was found on the skin and fins of perch.

Most of bream and perch parasites were autogenic species, such as myxosporeans, monogeneans, adult stages of digeneans and tapeworms, all nematode species, acanthocephalans, bivalves, leeches, and crustaceans. These included parasites with a direct life cycle (Myxosporea, monogeneans, crustaceans and leeches), for which both bream and perch represented definitive hosts. As far as parasites with a complex life cycle are concerned, bream served as an intermediate host for Diplostomum spp., $P$. cuticola, and $P$. ovatus and as the definitive host for the remaining digeneans, 3 tapeworm species, 2 nematodes, and acanthocephalan A. lucii. Perch was intermediate host for T. clavata, Diphyllobotrium sp., E. crassum, and $T$. nodulosus and definitive host for the tapeworm $P$. percae, nematode $H$. aduncum, and acanthocephalans $E$. gadi and P. laevis.

Allogenic parasites of bream were metacercariae of Diplostomum spp., P. cuticola, and P. ovatus and those of perch were metacercariae of $T$. clavata and plerocerkoid of Diphyllobothrium sp. The most frequent autogenic parasites were the tapeworm $C$. laticeps in bream, and digenean $B$. luciopercae, in perch.

The parasites of bream were mostly generalists. A group of specialists, or parasites linked with just one or two closely related host species, comprised 5 species in bream $(H$. cutanea, D. falcatus, D. paradoxum, Philometra ovata, and T. maculatus). All perch parasites were classified as generalists; the only exception was cestode Proteocephalus percae.

The most numerous group was represented by digeneans. Bream hosted 917 specimens (47.59\% of all parasites), with larval stages representing $98.4 \%$ of the total number. Perch was infected by 342 digeneans $(73.71 \%$ of all parasites), and larval stages represented $52.9 \%$.

\section{Discussion}

The list of bream parasites found in Poland comprises 96 species; in perch, 69 parasites have been recorded (Piasecki \& Woliński, in press). The parasitic fauna of bream and perch from the Szczecin Lagoon and Pomeranian Bay was much poorer, however the general proportions in relation to the individual host species were preserved. These results correspond with observations of Kennedy and Guegan (1994), who stated that the structure of parasites community depends on local conditions and the number of species in certain ecosystems is always lower than the number of species described for the host's entire range of distribution.

Our studies have revealed that the parasite fauna of bream is richer than that of perch. Chabaud and Durette-Desset (1978) explained that monophagous hosts, like bream, provide more stable conditions providing a better chance of survival to parasitic species as compared with polyphagous hosts.

A comparison of our results with data on the parasitic fauna of bream and perch from the period of $1967-1972$ (Grabda, 1973) shows that the quantitative and qualitative structure of parasite communities has changed. Parasites of bream that were found in both studies were digeneans $A$. imitans, P. cuticola, P. ovatus, and Diplostomum spp., as well as the copepod T. maculatus. The prevalence of Diplostomum spp. reached $100 \%$ in the study by Grabda (1973), whereas it was $16.67 \%$ in this study. The total number of species infecting perch was the same in both studies, but the species diversity of parasites has changed. In our study, we have not found the nematode Camallanus truncatus or the copepod Achtheres percarum. On the other hand, we detected M. dispar, P. geometra, as well as $P$. laevis, $H$. aduncum and $E$. gadi. The last two species are typical marine fish parasites and perch represents a new host in Poland. The prevalence of both acanthocephalans was very low (Table 2 ), whereas the nematode $H$. aduncum was found in the digestive tract of 11 fish.

The helminth fauna of bream studied by Rokicki (1975) in the Bay of Gdańsk (mouth of Vistula River) was poor, con- 
sisting of autogenic parasites, except for plerocercoids of Ligula intestinalis. Out of three digenean species mentioned by this author, only $A$. imitans was found in bream from the Odra River mouth and its prevalence was twice lower than that in the Bay of Gdańsk. The most common helminths of perch in the Bay of Gdańsk were intestinal digeneans (Rokicki, 1975), but only one of them, $B$. luciopercae, was also found in Pomeranian Bay and the Szczecin Lagoon. The parasites found in both basins were tapeworms $C$. laticeps in bream, and $P$. percae in perch. The prevalence of $C$. laticeps in bream in Pomeranian Bay was twice as high as that in the Bay of Gdańsk, while that of $P$. percae was twice lower.

The gill parasites of bream and perch have not been studied in the Szczecin Lagoon or the Bay of Gdańsk so-far (Grabda, 1973; Rokicki, 1975). The most common gill parasite of bream of the Odra River estuary was Myxobolus oviformis, first described in bream from Poland by Pojmańska et al. (1980). In perch, the spores of Henneguya psorospermica were once described in the Masurian lakes (El-Tantawy, 1989a, b).

The parasite community of the skin and fins of bream was the richest. Spores of Henneguya cutanea, which were found in 4 fish, have been first described by Dogiel and Petruschewsky, 1933 (Bychovsky, 1962) in perch living in the mouth of the river Neva. Piscicola geometra was found on the skin of the highest number of bream, but the most frequent parasite was the metacercaria of $P$. cuticola. Metacercariae Diplostomum spp. were dominant in bream in our study, which is in correspondence with results from the Lake Dabie (connected to the lower course of the Odra River), where metacercariae of Diplostomum spathaceum s.l. represented one of the dominant species (prevalence $12.4 \%$ ) (Wierzbicka, 1977). Such a high level of the prevalence could result from dense populations of intermediate hosts (Radix auricularia L., R. limosa L., Lymnaea stagnalis L., Galba palustris (Müll.)) (Sudarikov, 1960), which are preferably eaten by bream inhabiting this locality (Abdel-Baky, 1983).

Metacercaria of T. clavata was found in vitreous humour of infected 23 perch. The first intermediate hosts for this digenean are, as for $D$. spathaceum, Radix spp. and $L$. stagnalis (Jara \& Chodyniecki, 1999) and, therefore, the specificity of this parasite to the final host is of great interest (Kompowski, 1988; Szypuła, 1999). Most parasites have very little capability of recognizing their hosts, therefore another mechanism of sorting should be considered, namely selective survivability (Bush et al., 2002). Combes (1999) suggested that, for any type of host, only those individual parasites are able to survive that have the specialised genes allowing them to confront the immune response of the host. Thus, the host immune system affects the composition of the parasite infrapopulation.

Five parasites of bream were classified as specialists, while perch was the host to only one species exhibiting a narrow specificity. Price (1977) reflects that the more ancient host species harbour more specific parasites. This should result from better adaptation of parasites to the conditions offered by the host after a lapse of time because cyprinids are a more ancient group than percid fishes (Kirpičnikov, 1987). Generalist such as Piscicola geometra and larvae of Unionidae spp. were common parasites of both fish host species studied. Generalists that exhibit non-specialised requirements are most likely to spread and colonise many host species (Manter, 1967).

\section{Acknowledgements}

We would like to thank Dr George W. Benz from Middle Tennessee State University (USA) for his valuable comments on this manuscript, also Przemysław Romanowski and Sławomir Sochacki for their technical support.

\section{References}

ABDEL-BAKY, T. E. (1983): Some aspects on the biology of bream (Abramis brama L.) in Dąbie lake. Thesis. Agricultural University of Szczecin Press

Bush, A. O., Fernández, J. C., Esch, G., Seed, J. R. (2002): Parasitism: the diversity and ecology of animal parasites. Cambridge University Press

BYCHOVSKY, B. E. (Ed.). (1962): Key of parasites of freshwater fishes of SSSR. Akademiâ Nauk SSSR (in Russian)

Chabaud, A. G., Durette-Desset M. C. (1978): Parasitisme par plusieurs espèces congénérique. Bulletin de la Societé Zoologique de France 103: 459-464

COMBES, C. (1999): Interactions durables. Ecologie et évolution du parasitisme. Masson, Editeur, Paris

CZACHOROWSKI, S. (2004): Descriptive method of biocoenosis - zoocoenology. www.uwm.edu.pl/czachor/publik/ pdf-inne/zoocenozy.pdf (in Polish)

EL - TANTAWY, S. A. M. (1989a): Myxosporidian parasites of fishes in lakes Dgał Wielki and Warniak (Mazurian Lakeland, Poland) I. Survey of parasites. Acta Parasitol. Pol., 34: $203-219$

EL - TANTAWY, S. A. M. (1989 b): Myxosporidian parasites of fishes in lakes Dgał Wielki and Warniak (Mazurian Lakeland, Poland) II. Infection of fishes. Acta Parasitol. Pol., 34: 221 - 233

Esch, G., Kennedy, C. R., Bush, A. O., AHO, J. M. (1988): Patterns in helminths communities in freshwater fish in Great Britain: Alternative strategies for colonisation. Parasitology, 96: $519-532$

GRABDA, J. (1973): Fish parsites and diseases of Szczecin Lagoon. Proceed. of Sympos. on XX years of MIR, Gdynia: $61-67$ (in Polish)

JARA, Z., CHODYNIECKI, A. (1999): Ichthyopathology. Agricultural University of Wrocław Press (in Polish)

Kennedy, C. R., Guegan, J. F. (1994): Regional versus local helminth parasites richness in British freshwater fish: saturated or unsaturated parasite communities? Parasitology, 109: 175 - 185

KENNEDY, C. R., POJMAŃSKA T. (1996): Richness and diversity of helminth parasite communities in the common carp and in three more recently introduced carp species. $J$. 
Fish. Biol., 48: 89 - 100

KIRPIČNIKOV, V. S. (1987): Genetics and selection of fishes. Izdatelstvo Nauka, Leningrad (in Russian)

Khalil, L. F., Jones, A., BrAY, R. A. (1994): Keys to the Cestode Parasites of vertebrates. CAB International, University Press, Cambridge, UK

KompowsKi, A. (1988): Growth rate of bream, Abramis brama (L., 1758), in Lake Dąbie and the Szczecin Lagoon. Acta Ichthyologica et Piscatoria, 18: 35 - 48

MAJEWSKI, A. (1974): Hydrological characteristics of Pomeranian Bay. Communication and Contact Press. Warszawa (in Polish)

MANTER, H. (1967): Some aspects of the geographical distribution of parasites. Journal of Parasitology, 53: 1 - 9 PIASECKI, W., WOLIŃSKI, J. (in press): Catalogue of parasitic fauna of Poland. Part II. Parasites of cyclostomates and fishes (supplement 1970 - 2000). Agricultural University of Szczecin Press

PojmańsKa, T., Grabda-KazUbSKa, B., KazubsKi, S. L., MichalSKA, J., NIEWIADOMSKA, K. (1980): Parasite fauna on five fish species from the Konin lake complex, artificially heated with thermal effluents, and from Gopło lake. Acta Parasitol. Pol., 27: 319 - 357

POJMAŃSKA, T. (1993): Glossary of parasitological terms currently used in parasitology. Wiad. Parazytol., 39: $286-$ 287

PRICE, P. W. (1977): General concepts on the evolutionary biology of parasites. Evolution, 31: $405-420$

PRICE, P. W. (1980): Evolutionary biology of parasites. Princeton University Press. Princeton

RoKICKI, J. (1975): Helminth fauna of fishes of the Gdańsk Bay (Baltic Sea). Acta Parasitol. Pol., 23: 37 - 84 Scholz,T., Shimazu, T., Olson, P.D., Nagasawa K. (2001) : Caryophyllidean tapeworms (Platyhelminthes: Eucestoda) from freshwater fishes in Japan. Folia Parasitologica, 48: $275-288$

SudARIKOV, V. E. (1960): Order Strigeida (La Rue, 1926) Sudarikov, 1959. In: Skryabin, K. I. (Ed): Animals and human trematodes. (in Russian)

Szypuła, J. 1999. Age, growth and condition of perch in the Pomeranian Bay. Folia Universitatis Agriculture Stetinensis, Piscaria, 192: $79-87$

Trojan, P. (1992): Fauna structure analysis. Memorabilia Zoologica, 47: 1 - 120 (in Polish)

WiERZBICKA, J. (1977): Trematodes of Abramis brama, A. ballerus and Blicca bjoercna from the Dąbie Lake, Poland. Acta Parasitol. Pol., 25: 1 - 16 